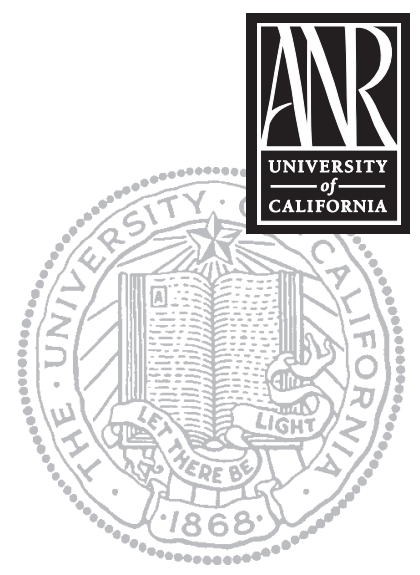

UNIVERSITY OF CALIFORNIA

Division of Agriculture and Natural Resources http://anrcatalog.ucdavis.edu
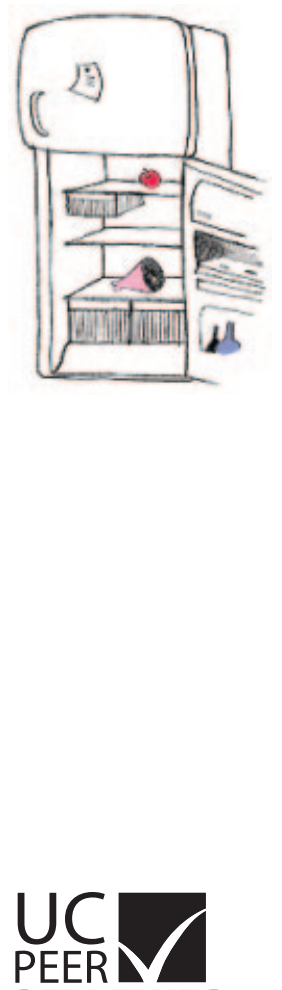

REVIEWED

\title{
Safe Handling of Fruits and Vegetables
}

CHRISTINE BRUHN, University of California Cooperative Extension Food Marketing Specialist, University of California, Davis; AMY LI-COHEN, Research Assistant, Department of Food Science and Technology, University of California, Davis; LINDA J. HARRIS, University of California Cooperative Extension Food Safety Specialist, University of California, Davis; illustrations by ANNE SPITLER-KASHUBA

Eating a variety of fruits and vegetables is healthy, but care must be taken to be sure fruits and vegetables do not become contaminated with harmful bacteria. In the United States, one out of four people suffers from foodborne illness each year. Some of these illnesses have been traced to eating raw fruits or vegetables.

Everyone is at risk for foodborne illness, but people who are younger than 5 , older than 50, diabetic, take antibiotics or antacids, and whose immunity is compromised are at higher risk.

Bacteria are everywhere. Harmful bacteria may be on fruits and vegetables, hands, and kitchen counters and sinks, even when they look, feel, or smell clean.

This publication provides guidelines for protecting you from harmful bacteria.

\section{AT THE SUPERMARKET}

In the grocery cart, separate fruits and vegetables from meat, poultry, and fish to avoid cross-contamination.

When bagging fresh fruits and vegetables to take home from the supermarket, put fresh produce and meat, poultry, and fish in separate bags.

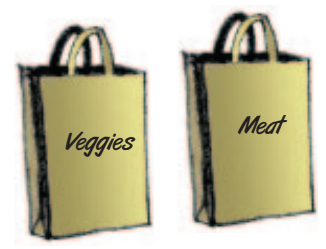

\section{HOME STORAGE}

All cut or prepared fruits and vegetables should be stored in the refrigerator along with many types of whole fruits and vegetables.

When using the refrigerator, place produce in the produce drawer or on a refrigerator shelf.

Store meat, poultry, and fish in the clean meat drawer or on a tray on the bottom shelf below other refrigerated foods. This prevents meat, poultry, or fish juices from dripping on other foods.

\section{PREPARE THE KITCHEN}

Clean the sink with hot, soapy water or cleanser before and after washing and preparing fresh fruits and vegetables.

Always wash cutting boards and preparation areas before and after food prepara-

tion. Wash preparation areas and utensils especially well after preparing meat, poultry, or fish and before preparing foods that will be eaten without cooking.

If possible, use one cutting board and preparation area for fresh fruits and vegetables and a different cutting board and preparation area for meat, poultry, and fish.

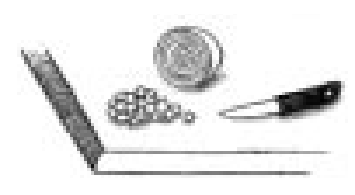

Always wash knives after cutting meat, poultry, or fish with hot soapy water before cutting fresh fruits and vegetables; or, use different knives for cutting meat products and fresh produce. 


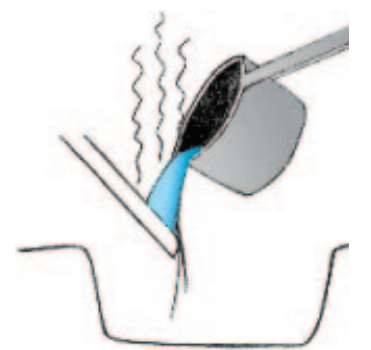

\section{WASH YOUR HANDS}

Always wash hands with hot, soapy water for at least 20 seconds before and after handling fresh fruits and vegetables.

\section{WASH ALL FRUITS AND VEGETABLES}

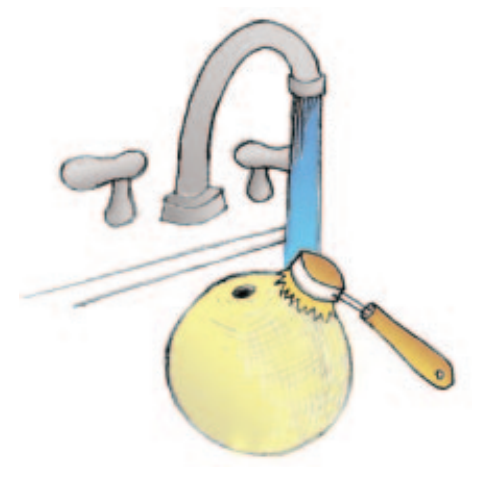

Always wash fruits and vegetables, including those that are organically grown, come from a farmer's market, or were grown in your own garden.

Wash fruits and vegetables just before cooking or eating.

Wash under running water.

When possible, scrub fruits and vegetables with a clean scrub brush or with hands. For melons, scrub the rind with a brush under running water before cutting or peeling. This removes bacteria before it is spread by the knife when slicing. Sanitize the brush by putting it in the dishwasher, placing it in boiling water for 20 seconds, or rinsing it in a bleach solution of 1 teaspoon chlorine bleach in 1 quart ( 4 cups) of water.

Dry fruits and vegetables with disposable paper towels.

Do not use antibacterial soaps or dish detergents to wash fruits and vegetables because soap or detergent residues can remain on the produce. The FDA has not evaluated the safety of the residues that could be left from soaps and detergents. Some commercial cleaning solutions specifically designed for fresh fruits and vegetables may help remove additional dirt on some types of produce. However, the effectiveness of these washes is not currently standardized.

Soaking fruits and vegetables in water is not recommended because of the potential for cross-contamination.

Remove outer green leaves from items like lettuce or cauliflower before washing. Trim the hull or stem from items like tomatoes, strawberries, and peppers after washing.

Ready-to-eat, prewashed, bagged produce can be used without further washing if it has been kept refrigerated and is used by the "use-by" date. If desired, produce can be washed again under running water.

Precut or prewashed produce sold in open bags or containers should always be washed under running water before using.

\section{REFRIGERATE ALL LEFTOVERS}

Peel leftover melons and store the fruit in the refrigerator. Store all cut produce in a clean container in the refrigerator. 


\section{FOR MORE INFORMATION}

\section{Useful Web sites}

USDA/FDA Foodborne Illness Education Information Center

http://www.nal.usda.gov/foodborne/index.html

U.S. FDA/Center for Food Safety and Applied Nutrition

http://vm.cfsan.fda.gov/list.html

Gateway to Government Food Safety Information

http://www.foodsafety.gov/

\section{ANR Communication Services Publications}

You'll find more information on food safety in the following ANR Communication Services publications available for free downloading at http://anrcatalog.ucdavis.edu:

Cantaloupe: Safe Methods to Store, Preserve, and Enjoy, Publication 8095, 2003

Garlic: Safe Methods to Store, Preserve, and Enjoy, Publication 7231, 1997

Peppers: Safe Methods to Store, Preserve, and Enjoy, Publication 8004, 1998

Safe Methods of Canning Vegetables, Publication 8072, 2003

Guidelines for Food Safety during Short-Term Power Outages: Consumer Fact Sheet, Publication 7264, 2002

For other products, visit the ANR Communication Services online catalog at http://anrcatalog.ucdavis.edu. You can also place orders by mail, phone, or fax, or request a printed catalog of publications, slide sets, CD-ROMs and videos from

University of California

Agriculture and Natural Resources

Communication Services

6701 San Pablo Avenue, 2nd Floor

Oakland, California 94608-1239

Telephone: (800) 994-8849 or (510) 642-2431; FAX: (510) 643-5470

E-mail inquiries: danrcs@ucdavis.edu

An electronic version of this publication is available on the ANR Communication Services Web site at http://anrcatalog.ucdavis.edu.

\section{Publication 8121}

(C) 2004 by the Regents of the University of California, Division of Agriculture and Natural Resources. All rights reserved.

The University of California prohibits discrimination against or harassment of any person employed by or seeking employment with the University on the basis of race, color, national origin, religion, sex, physical or mental disability, medical condition (cancer-related or genetic characteristics), ancestry, marital status, age, sexual orientation, citizenship, or status as a covered veteran (special disabled veteran, Vietnam-era veteran or any other veteran who served on active duty during a war or in a campaign or expedition for which a campaign badge has been authorized). University Policy is intended to be consistent with the provisions of applicable State and Federal laws.

Inquiries regarding the University's nondiscrimination policies may be directed to the Affirmative Action/Staff Personnel Services Director, University of California, Agriculture and Natural Resources, 300 Lakeside Drive, 6th Floor, Oakland, CA 94612-3550 (510) 987-0096. For a free catalog of other publications, call (800) 994-8849. For help downloading this publication, call (530) 754-5112.

This publication has been anonymously peer reviewed for technical accuracy by University of California scientists and other qualified professionals. This review process was managed by the ANR Associate Editor for Food and Nutrition. 